\title{
PENYULUHAN TENTANG TATA KELOLA DAN PERTANGGUNGJAWABAN DANA DESA DI DESA SUKAMULIA TIMUR KECAMATAN SUKAMULIA KABUPATEN LOMBOK TIMUR
}

\author{
Satarudin ${ }^{1}$, Moh. Huzaini' ${ }^{2}$, Jalaludin ${ }^{3}$ \\ Fakultas Ekonomi dan Bisnis - Universitas Mataram \\ satarudin1969@gmail.com
}

\begin{abstract}
ABSTRAK
UU Nomor 6 Tahun 2014 beserta peraturan pelaksanaanya telah mengamanatkan pemerintah desa untuk lebih mandiri dalam mengelola pemerintahan dan berbagai sumber daya alam yang dimiliki, termasuk di dalamnya pengelolaan keuangan dan kekayaan milik desa. Penyuluhan tentang tata kelola dan pertanggung jawaban dana desa di desa Sukamulia Timur kecamatan Sukamulia kabupaten Lombok Timur ini bertujuan untuk: 1). meningkatkan pengetahuan dan pemahaman aparatur desa tentang tata kelola dana atau keuangan desa yang meliputi tahap perencanaan dan pelaksanaan pengelolaan keuangan desa, 2). meningkatkan kemampuan teknis akuntansi bagi aparateur desa terutama unit pengelola dana atau keuangan desa yang mencakup penatausahaan dan pelaporan keuangan desa. Beberapa kesimpulan dari pelaksanaan pengabdian masyarakat ini adalah; Pengabdian masyarakat ini sangat bermamfaat, karena berkesuaian dengan kebutuhan desa yang sedang menatalaksanakan pengelolaan dana desa, terutama yang bersumber dari dana pusat atau APBN. Selain itu materi pengabdian sangat pas dengan kebutuhan desa terutama yang terkait dengan tata kelola dan akuntabilitas atau pertanggung jawaban serta pelaporan dana desa terutama yang bersumber dari APBN. Secara tekhnis pelaksanaan pengabdian ini cukup komunikatif dan interaktif karena dapat melibatkan peserta secara aktif dalam penyajian materinya.
\end{abstract}

Kata kunci: Pengelolaan dan pertanggungjawaban dana

\begin{abstract}
Law Number 6 of 2014 and its implementation regulation have mandated a more independent village government in managing its governanceand the various village's natural resources, including assets and financial management. The counseling on managing and accountability village funds in East Sukamulia village, Sukamulia sub-district, East Lombok district, aims to 1). Increase the village officials' knowledge and understanding of the village funds or financial management, including planning and implementation stages; 2). Improve the village officials'
\end{abstract}


technical accounting skills, especially the village fund or financial management unit, including the village financial reporting and administration. in conclusion, the community service program is very beneficial because it is following the village's needs, such as managing the village funds, especially those sourced from central funds or APBN. Also, its material fits the village's demand perfectly within the governance, accountability, and the village funds reporting, especially those sourced from the APBN. Technically, it is very communicative and interactive because it can involve participants actively in presenting the material.

Key word: Governance and accountability of Funds

\section{PENDAHULUAN}

UU Nomor 6 Tahun 2014 beserta peraturan pelaksanaanya telah mengamanatkan pemerintah desa untuk lebih mandiri dalam mengelola pemerintahan dan berbagai sumber daya alam yang dimiliki, termasuk di dalamnya pengelolaan keuangan dan kekayaan milik desa.

Dalam UU Desa pasal 72, desa memiliki Pendapatan Asli Desa dan Pendapatan Transfer berupa Alokasi Dana Desa; Bagian dari Hasil Pajak dan Retribusi Kabupaten/Kota; dan Bantuan Keuangan dari APBD Provinsi/ Kabupaten/Kota Peran besar yang diterima oleh desa, tentunya disertai dengan tanggung jawab yang besar pula. Oleh karena itu pemerintah desa harus bisa menerapkan prinsip akuntabilitas dalam tata pemerintahannya, dimana akhir dari semua kegiatan penyelenggaraan pemerintahan desa harus dapat dipertanggung jawabkan kepada masyarakat desa sesuai dengan ketentuan yang berlaku.

Dalam hal keuangan desa, pemerintah desa wajib menyusun Laporan Realisasi Pelaksanaan APB Desa dan Laporan Pertanggungjawaban Realisasi Pelaksanaan APB Desa. Laporan ini dihasilkan dari suatu siklus pengelolaan keuangan desa,yang dimulai dari tahapan perencanaan dan penganggaran;

pelaksanaan dan penatausahaan; hingga pelaporan dan pertanggungjawaban pengelolaan keuangan desa.

Dalam tahap perencanaan dan penganggaran, pemerintah desa harus melibatkan masyarakat desa yang direpresentasikan oleh Badan 


\section{Jurnal ABDIMAS INDEPENDEN}

Vol. 2, No. 2, November 2021

Permusyawaratan Desa (BPD), sehingga program kerja dan kegiatan yang disusun dapat mengakomodir kepentingan dan kebutuhan masyarakat desa serta sesuai dengan kemampuan yang dimiliki oleh desa tersebut. Selain itu pemerintah desa harus bisa menyelenggarakan pencatatan, atau minimal melakukan pembukuan atas transaksi keuangannya sebagai wujud pertanggungjawaban keuangan yang dilakukannya. Namun demikian, peran dan tanggung jawab yang diterima oleh desa belum diimbangi dengan sumber daya manusia (SDM) yang memadai baik dari segi kuantitas maupun kualitas.

Kendala umum lainnya yaitu desa belum memiliki prosedur serta dukungan sarana dan prasarana dalam pengelolaan keuangannya serta belum kritisnya masyarakat atas pengelolaan anggaran pendapatan dan belanja desa. Besarnya dana yang harus dikelola oleh pemerintah desa memiliki risiko yang cukup tinggi dalam pengelolaannya, khususnya bagi aparatur pemerintah desa.

\section{Solusi Dan Target Luaran}

Untuk mengatasi persoalan seperti yang di uraikan di atas, maka solusi yang ditawarkan dalam kegiatan Pengabdian pada Masyarakat (PPM) ini adalah :

1. Meningkatkan pengetahuan dan pemahaman aparateur desa tentang tata kelola dana atau keuangan desa yang meliputi tahap perencanaan dan pelaksanaan pengelolaan keuangan desa.

2. Meningkatkan kemampuan teknis akuntansi bagi aparateur desa terutama pengelola dana atau keuangan desa yang mencakup penatausahaan dan pelaporan keuangan desa.

Target luaran dari Kegiatan pengabdian masyarakat yang dilaksanakan di desa Sukamulia Timur kecamatan Sukamulia ini adalah :

1. Meningkatnya pengetahuan dan pemahaman aparateur desa tentang tata kelola dana atau keuangan desa yang meliputi tahap perencanaan dan pelaksanaan pengelolaan keuangan desa. 
2. Meningkatnya kemampuan teknis akuntansi bagi aparateur desa terutama pengelola dana atau keuangan desa yang mencakup penatausahaan dan pelaporan keuangan desa.

\section{METODE KEGIATAN}

Penyampaian materi penyuluhan dilakukan dengan menggunakan metode ceramah dan dan dilengkapi dengan metode tanya jawab. Metode ceramah adalah salah satu metodologi pembelajaran yang penyampaian informasi pembelajaran kepada peserta didik dilakukan dengan cara lisan. Metode ceramah bisa aplikasikan di dalam kelas atau di dalam gedung dengan jumlah peserta yang relatip banyak. Dengan menggunakan metode ini, seorang pengajar atau penceramah akan lebih mudah menjelaskan materi-materinya. Bahkan proses pembelajaran akan berjalan dengan efektif.

\section{HASIL DAN PEMBAHASAN}

Peserta yang hadir terdiri dari, sekretaris desa, unsure kepala urusan (kaur) kantor desa, kepala dusun atau lingkungan, pengurus/ anggota Badan Perwakilan Desa (BPD), Unit Pelaksana Keuangan (UPK) dan tokoh masyarakat lainnya termasuh tokoh agama yang kurang lebih berjumlah 22 orang (daftar hadir terlampir).

Kegiatan pengabdian ini dilaksanakan dengan susunan acara sebagai berikut:

1. Pembukaan

2. Sambutan Kepala desa

3. Acara inti atau penyampaian materi penyuluhan.

4. Diskusi atau tanya jawab dan

5. Penutup.

Acara dimulai pukul 10.00 Wita, dipandu oleh Sekretaris desa yaitu Bapak Sarifuddin, SE. Sementara itu Kepala desa Sukamulia Timur Bapak Zainul 


\section{Jurnal ABDIMAS INDEPENDEN}

Vol. 2, No. 2, November 2021

Wardi. Dalam kata sambutannnya menyampaikan bahwa acara "Penyuluhan Tentang Tata Kelola dan Pertanggung Jawaban Dana Desa" sangat penting dan sangat bermanfaat bagi aparateur desa termasuk dirinya sendiri selaku pemangku amanah dan tanggung jawab dalam perencanaan dan pelaksanaan penmbangunan di desa Sukamulia Timur, termasuk didalamnya adalah masalah peñata usahaan atau tata kelola dana desa yang selama ini dirasa belum optimal. Oleh karena itu dengan adanya kegiatan pengabdian ini diharapkan bisa menambah pengetahuan dan secara teknis operasional dapat meningkatkan kemampuan jajaran pemerintah desa dalam mengelola keuangan desa baik yang bersumber dari Pendapatan Asli Desa maupun yang berasal dari transfer bagi hasil dari pemerintah kabupaten maupun Provinsi serta yang tak kalah pentingnya adalah dana yang bersumber dari pusat yang alokasikan melalui Anggaran Pendapatan dan Belanja Negara (APBN). Acara kemudian dilanjutkan dengan penyampaian materi pengabdian yang disampaikan secara bergiliran oleh tim pengabdian FEB UNRAM. Adapun materi yang disampaikan adalah :

1. Pengertian desa baik secara istilah atau bahasa maupun menurut Undang- Undang atau peraturan yang berlaku yang dalam hal ini adalah UU No.6 th 2014, Permendagri no. 20 th 2018.

2. Kewenangan desa: Self Governing Community dan Local Self Government

3. Tata Kelola keuangan desa yang meliputi Perencanaan, Pelaksanaan, Penatausahaan, Pelaporan dan Pertanggungjawaban.

Materi tata kelola dan pertanggung jawaban pengelolaan dana desa, diawali dengan materi mengenai tujuan pembangunan desa, sumber- sumber pendanaan pembangunan desa dan sekala prioritas yang bisa dilakukan dalam pengelolaan dana desa. Materi selanjutnya yaitu akuntabilitas atau pertanggung jawaban pemerintah desa dalam mengelola dan mendayagunakan dana pembangunan desa yang berasal dari berbagai sumber. Terkait dengan hal ini maka dijelaskan mengenai bentuk pertanggung jawaban kepala desa dalam melaksanakan pengelolaan keuangan desa hususnya dana desa yang berasal dari pemerintah pusat/ 
APBN, yaitu dalam bentuk laporan pertanggung jawaban yang harus dibuat oleh kepala desa. Dalam hal ini pemerintah esa harus membuat dua macam laporan yaitu 1). Laporan ke Bupati/ Walikota dan 2). Laporan ke Badan Perwakilan Desa (BPD).

Adapun penyampaian materi penyuluhan seperti yang telah diuraikan sebelumnya, dilakukan dengan metode ceramah, yaitu penyajian materi secacara lisan dengan menggunakan alat bantu laptop dan LCD.

Dipilihnya metode ceramah dalam kegiatan pengabdian ini karena metode ceramah sebagaimana metode yang lain, memiliki kebaikan. Ada beberapa kebaikan Metode Ceramah, antara lain:

1. Dapat menampung kelas besar dan tiap siswa mempunyai kesempatan yang sama untuk mendengarkan. Oleh karenanya biaya yang diperlukan lebih murah.

2. Bahan pelajaran dapat diberikan secara urut, ide atau konsep dapat direncanakan dengan baik.

3. Penceramah/ fasilitator dapat menekankan hal-hal yang penting, sehingga waktu dan energi dapat digunakan sehemat mungkin.

4. Materi ceramah/ silabus dapat dilakukan menurut jadwal, karena fasilitator tidak harus menyesuaikan dengan kecepatan belajar siswa.

5. Kekurangan atau tidak adanya buku pelajaran dan alat bantu pelajaran tidak menghambat jalanya pelajaran.

Adapun dukumentasi kegiatan pengabdian masyarakat ini dapat dilihat pada gambar berikut ini

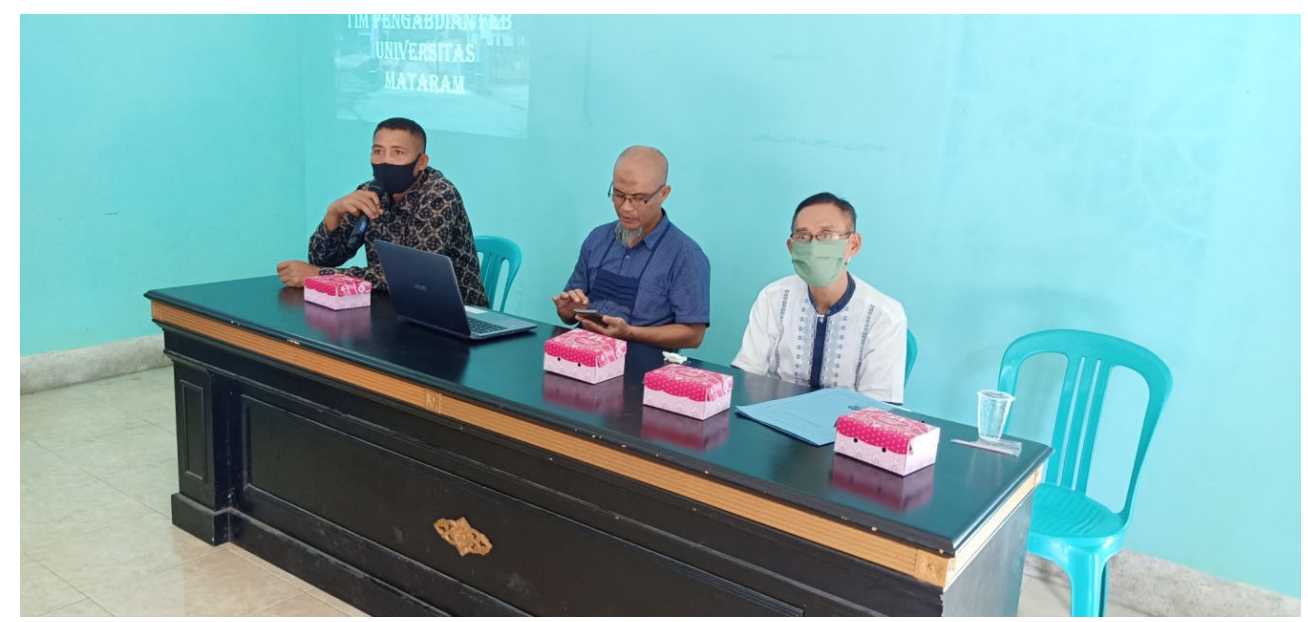




\section{Jurnal ABDIMAS INDEPENDEN}

Vol. 2, No. 2, November 2021

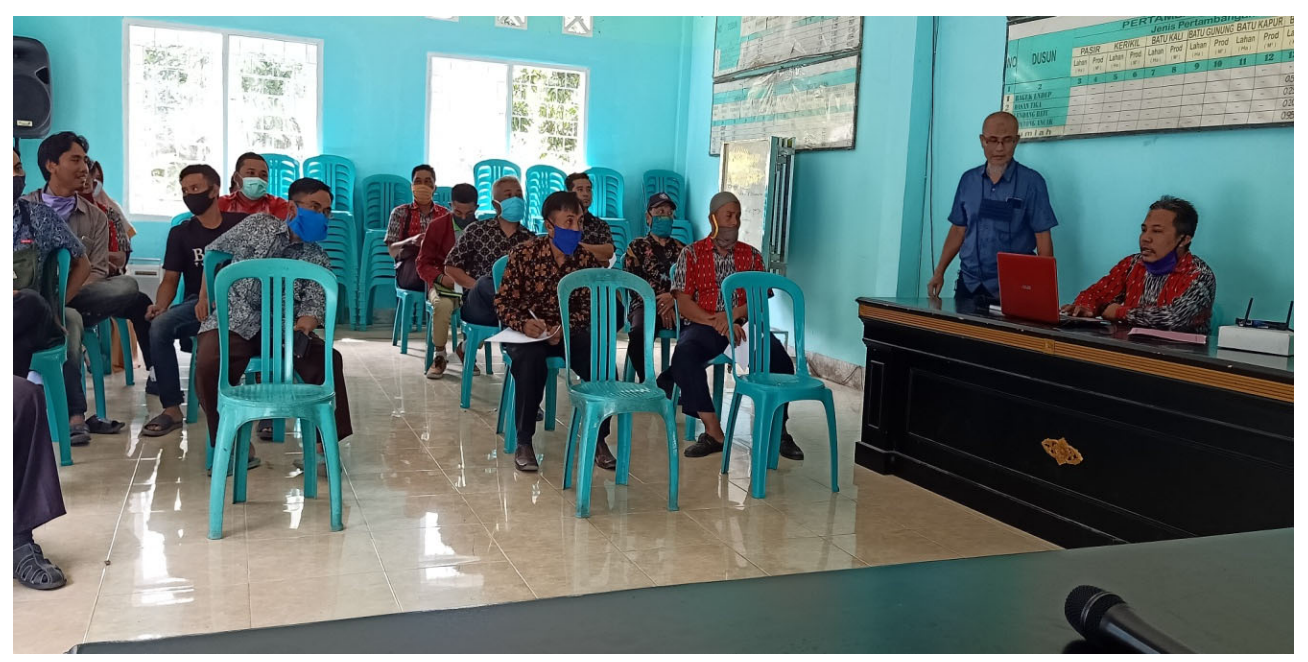

\section{KESIMPULAN DAN SARAN}

1. Pengabdian masyarakat ini sangat bermamfaat, karena berkesuaian dengan kebutuhan desa yang sedang menatalaksanakan pengelolaan dana desa, terutama yang bersumber dari dana pusat atau APBN.

2. Materi pengabdian sangat pas dengan kebutuhan desa terutama yang terkait dengan tata kelola dan akuntabilitas atau pertanggung jawaban serta pelaporan dana desa terutama yang bersumber dari APBN

3. Secara tekhnis pelaksanaan pengabdian ini cukup komonikatif dan interaktif karena dapat melibatkan peserta secara aktif dalam penyajian materinya. Namun karena terbatasnya waktu peran aktif dari peserta pengabdian belum bisa maksimal.

\section{UCAPAN TERIMA KASIH}

Terlaksananya kegiatan Pengabdian Kepada Masyarakat ini, tidak terlepas dari peran berbagai pihak. Oleh karena itu pada kesempatan ini kami (Tim pengabdian) mengucapkan terima Kasih dan penghargaan kepada: 
1. Ketua LPPM Unram yang telah menyediakan dana pengabdian yang bersumber dari PNBP

2. Kepala Desa Sukamulia Lombok Timur, dan Sekertaris Desa beserta staff yang telah mendukung kegiatan pengabdian dengan menyiapkan ruangan (AULA kantor desa) dan fasilitas pendukung lain yang diperlukan.

\section{DAFTAR PUSTAKA}

Anonim, 2014, Peraturan Menteri Dalam Negeri Nomor 113 Tentang 2014 Tentang Pengelolaan Keuangan Desa, Kementerian Dalam Negeri RI, Jakarta.

Anonim, 2014 Undang-Undang Nomor 6 Tahun 2014 Tentang Desa, Kementerian Dalam Negeri RI, Jakarta.

Akuntan Indonesia, Januari-Februari 2015, "IAI Siap Sukseskan Akuntabilitas Dana Desa"

Rosalinda, Okta, 2014, Pengelolaan Alokasi Dana Desa (ADD) Dalam Menunjang Pembangunan Desa (Studi Kasus : Desa Segodorejo dan Desa Ploso Kerep, Kecamatan Subomito, Kabupaten Jombang). Artikel Jurusan Ilmu Ekonomi, Fakultas Ekonomi dan Bisnis, Universitas Brawijaya Malang. Diunduh dari http://download.portalgaruda.org tanggal 28 maret 2015

Subroto, Agus, 2009, Akuntabilitas Pengelolaan Dana Desa (Studi Kasus Pengelolaan Dana Desa di Desa-desa Dalam Wilayah Kecamatan Tlogomulyo Kabupaten Temanggung Tahun 2008), Tesis Program Magister Sains Akuntansi, Universitas Diponegoro, Semarang

Thomas, 2013, Pengelolaan Alokasi Dana Desa Dalam Upaya Meningkatkan Pembangunan Desa Sebawang Kecamatan Sesayap kabupaten Tana Tidung. eJournal Pemerintahan Integratif. Diunduh dari www.ejournal.pin.or.id tanggal 28 Maret 2015 